\title{
HUBUNGAN IMPLEMENTASI RELATIONSHIP MARKETING DENGAN LOYALITAS NASABAH PADA PT. BANK BRI SYARIAH KANTOR CABANG BENGKULU
}

\author{
Meiffa Herfianti, Diman Wido Saputra \\ Fakultas Ekonomi Universitas Dehasen Bengkulu \\ meiffaherfianti@gmail.com
}

\begin{abstract}
ABSTRAK
Meiffa Herfianti, Diman Wido Saputra; Tujuan penelitian ini adalah untuk mengetahui apakah ada hubungan antara penerapan relationship marketing dengan loyalitas pelanggan pada PT. Bank BRI Kantor Cabang Syariah Bengkulu. Penelitian ini menggunakan analisis kualitatif dan kuantitatif, metode pengumpulan data menggunakan kuesioner, diuji dengan menggunakan rumus rank spearman dan uji hipotesis.

Berdasarkan hasil perhitungan rank Spearman didapatkan nilai koefisien korelasi rank spearman atau rho count (p) sebesar 0,765 berada pada interval korelasi 0,60 - 0,799 dengan kriteria kuat, artinya implementasi hubungan pemasaran memiliki hubungan yang kuat dengan loyalitas pelanggan. di PT. Bank BRI Kantor Cabang Syariah Bengkulu. Berdasarkan uji hipotesis koefisien korelasi rank spearman diperoleh t hitung 9,792 maka nilai t hitung dibandingkan dengan nilai t tabel pada tingkat kepercayaan 95\% atau tingkat kesalahan 5\% diketahui nilai t tabel adalah 1,66757 berarti bahwa nilai t hitung lebih besar dari nilai $t$ tabel $(9,792>1,66757)$ maka hipotesis yang diajukan dalam penelitian ini diterima artinya ada hubungan positif yang signifikan antara variabel pemasaran relaionship (X) dengan loyalitas pelanggan (Y) pada PT. Bank BRI Kantor Cabang Syariah Bengkulu.
\end{abstract}

\section{ABSTRACT}

Meiffa Herfianti, Diman Wido Saputra; The purpose of this study is to determine whether there is a relationship between the implementation of relationship marketing with customer loyalty at PT. Bank BRI Syariah Branch Office of Bengkulu. This research uses qualitative and quantitative analysis, data collection method using questionnaire, tested by using rank spearman formula and hypothesis test.

Based on the calculation of Spearman rank obtained correlation coefficient value of spearman rank or rho count ( $p$ ) amount 0,765 is at the correlation interval 0,60-0,799 with strong criteria, meaning that the implementation of relationship marketing has a strong relationship with customer loyalty at PT. Bank BRI Syariah Branch Office of Bengkulu. Based on the hypothesis test of spearman rank correlation coefficient obtained $t$ count 9,792 then the value of $t$ arithmetic is compared with the value of $t$ table at the level of confidence 95\% or error rate 5\% known value of $t$ table is 1.66757 means that the value of $t$ arithmetic greater than the value of t table $(9,792>1,66757)$ then the hypothesis proposed in this study is acceptable means there is a significant positive relationship between variable relaionship marketing $(X)$ with customer loyalty (Y) at PT. Bank BRI Syariah Branch Office of Bengkulu.

Key Words: Understand Customer Expectation, Cooperation With Customer, Total Quality Management And Employee Empowerment, Customer Loyalty

\section{LATAR BELAKANG}

Perubahan dalam dunia usaha yang semakin cepat mengharuskan perusahaan untuk merespon perubahan yang terjadi. Sektor jasa merupakan sektor yang paling besar mengalami perubahan akibat dari cepatnya perubahan yang dialami faktor lain, seperti perubahan teknologi yang secara langsung menaikan iklim kompetisi di dalam industri. Masalah yang dihadapi perusahaan-perusahaan jasa saat ini adalah cara menarik pelanggan dan mempertahankannya agar perusahaan dapat bertahan dan berkembang. Tujuan tersebut akan tercapai jika perusahaan melakukan proses pemasaran,

Pemasaran merupakan salah satu kegiatan pokok yang dilakukan oleh perusahaan untuk mempertahankan kelangsungan hidupnya Kotler dan Amstrong, (2012:229). Dalam pemasaran modern seperti saat ini, paragdima pemasaran telah bergeser, tidak hanya menciptakan transaksi untuk mencapai keberhasilan pemasaran tetapi perusahaan juga harus menjalin hubungan dengan pelanggan dalam waktu yang panjang. Relationship marketing diartikan sebagai menarik, memelihara dan meningkatkan hubungan dengan pelanggan (Wibowo, 2010:243).

Relationship marketing lebih merupakan pendekatan bersifat jangka panjang. Hal ini berbeda dengan pendekatan pemasaran transaksional yang lebih berorientasi jangka pendek. Tujuan dari 
pemasaran transaksional adalah untuk mendapatkan pelanggan semata, sedangkan tujuan dari relationship marketing adalah untuk mendapatkan dan mempertahankan pelanggan. Pada dasarnya relationship marketing adalah hubungan dan ikatan jangka panjang antara produsen, konsumen dan pemasok serta pelaku lainnya.

Esensi relationship marketing menyangkut hubungan yang langgeng dan pertukaran yang terus menerus serta dituntut untuk saling percaya dan ketergantungan. Sehingga dalam konsep relationship marketing, pemasar sangat menekankan pentingnya hubungan baik jangka panjang dengan konsumen dan infrastruktur pemasaran, yang dapat menciptakan kesadaran dalam bentuk hubungan dan komitmen yang menyeluruh. Jalinan relasi dalam relationship marketing berlangsung terus menerus dalam jangka panjang dan tidak berhenti hanya pada satu transaksi penjualan Rivai dan Basri, 2014:132).

Terdapat empat variabel yang digunakan perusahaan dalam mengimplementasikan Relationship Marketing yaitu: Memahami Harapan Pelanggan (Understanding Customer Expectation), Kerjasama Dengan Pelanggan (building service partnership), Total Quality Management dan pemberdayaan karyawan (empowering employees) Evans dan Laskin dalam (wibowo, 2010:271). Implementasi konsep relationship marketing memungkinkan adanya loyalitas pelanggan, karena relationship marketing berusaha memantapkan, memelihara, dan memperkuat hubungan antara organisasi dengan pelanggan, dengan memandang pelanggan sebagai prioritas. Loyalitas adalah sejauh mana seorang pelanggan menunjukkan sikap positif terhadap suatu merek, mempunyai komitmen pada merek tertentu, dan berniat untuk terus membelinya di masa depan. Pelanggan yang loyal dapat memantapkan sumber pembiayaan institusi, sekaligus menjadi strong word of mouth mempunyai kecenderungan lebih rendah untuk berpindah (Ali Hasan, 2013:122).

Loyalitas Nasabah adalah sikap yang ditujukan oleh konsumen terhadap penyediaan produk atau jasa. Seorang konsumen akan menunjukkan sikap loyalnya jika suatu perusahaan mampu memberikan kepuasan kepada konsumennya. Loyalitas merupakan perilaku konsumen yang akan dapat diketahui jika konsumen telah melakukan pembelian kepada produk yang ditawarkan di pasar. Konsumen yang loyal adalah mereka yang berkomitmen tinggi untuk membeli kembali dan berlangganan suatu produk atau jasa secara konsisten dimasa yang akan datang, sehingga dapat menyebabkan pengulangan pembelian merek yang sama.

Menurut Kotler dan Amstrong, (2012:386) perilaku pembelian ulang dalam situasi sensitivitas merek yang kuat dikategorikan sebagai loyalitas, dimana konsumen cenderung membeli ulang merek yang sama dan menganggap pilihan merek sangat penting baginya. Indikator dari loyalitas pelanggan menurut Kotler dan Keller (2012:57) adalah Kepercayaan Nasabah Pada Perusahaan, Membeli Ulang Produk, Nasabah Tidak Menggunakan Jasa Bank Lain, Merekomendasikan Pada Orang Lain. Penelitian ini dimaksudkan sebagai upaya pengembangan studi empiris tentang hubungan implementasi relationship marketing dengan loyalitas pelanggan. Alasan yang mendasari topik penelitian ini adalah bahwa setiap perusahaan jasa dalam mempertahankan pelanggannya, harus mampu menjalin hubungan yang baik dalam jangka panjang dan relationship marketing merupakan salah satu strategi yang dapat diimplementasikan untuk menunjang tercapainya tujuan tersebut. Relationship marketing yang berhasil akan membentuk pelanggan yang loyal (Prasasti, 2013:92). Loyalitas pelanggan merupakan isu yang dipertimbangkan penting untuk diteliti, karena isu ini diperkirakan berimplikasi pada profitabilitas dan kinerja sebuah perusahaan dalam jangka panjang.

Sebagai obyek dalam penelitian ini adalah nasabah PT. Bank BRI Syariah Kantor Cabang Bengkulu. PT. Bank BRI Syariah Kantor Cabang Bengkulu merupakan sebuah perusahaan yang bergerak pada jasa perbankan syariah, dimana pelanggannya memiliki kebutuhan jangka panjang (long time horizon), dengan kondisi tersebut disadari pentingnya konsep relationship marketing. Konsep ini mengharapkan adanya inovasi produk, peningkatan kualitas pelayanan dan peningkatan fasilitas agar dapat menciptakan loyalitas nasabah terhadap PT. Bank BRI Syariah Kantor Cabang Bengkulu, sehingga tercipta hubungan jangka panjang yang harmonis antara perusahaan dan nasabah. Hubungan jangka panjang dengan nasabah perlu dipertahankan karena nasabah merupakan merupakan elemen penting yang menentukan dapat atau tidaknya suatu bank untuk tumbuh dan terus berkembang.

\section{LANDASAN TEORI Relationship Marketing}

Konsep pemasaran relasional (relationship marketing) digunakan untuk menggambarkan beragam konteks dan perspektif aktivitas pemasaran Kotler dan Amstrong, (2012:62). Dalam perspektif sempit, pemasaran relasional menggambarkan beragam taktik pemasaran, untuk mengikat atau mempertahankan pelanggan setelah penjualan terjadi, dengan tujuan untuk menciptakan pembelian ulang (customer retention). Pada perspektif luas, pemasaran relasional digunakan sebagai paradigma dan 
orientasi pemasaran, sebagai oposisi dari transactional marketing. Berikut beberapa hal yang membedakan antara transactional marketing dan relationship marketing Kotler dan Amstrong,( 2012:87):

Tabel 1. Perbedaan Transactional Marketing dan Relationship Marketing

\begin{tabular}{|c|c|c|}
\hline Aspek & Transactional Marketing & Relationship Marketing \\
\hline Fokus & Fokus Pada Penjualan & $\begin{array}{c}\text { Fokus Pada Mempertahankan } \\
\text { Konsumen }\end{array}$ \\
\hline Orientasi & Orientasi Pada Karakterisrik Produk & Orientasi Pada Manfaat Produk \\
\hline skala waktu & Skala Waktu Jangka Pendek & Skala Waktu Jangka Panjang \\
\hline $\begin{array}{c}\text { Komitmen Kepada } \\
\text { Konsumen }\end{array}$ & komitmen terbatas & Komitmen Tinggi \\
\hline kontak & Kontak Dengan Konsumen Rendah & kontak dengan konsumen tinggi \\
\hline kualitas & Kualitas Adalah Urusan Bagian & Kualitas Adalah Urusan Semua \\
& Operasi & Departemen \\
\hline
\end{tabular}

Sumber: Kotler dan Amstrong, (2012:89)

Beberapa peneliti menggambarkan relationship marketing sebagai ikatan jangka panjang (long term relationship) antara dua pihak. Ikatan tersebut dapat berupa ikatan antar perusahaan yang dikenal dengan pola Business to Business (supplier dan distributor atau manufaktur dengan distributor) atau ikatan antara perusahaan dengan pelanggan yang biasa disebut Business to Customer (perusahaan atau organisasi dengan konsumen atau pelanggannya).

Kotler dan Armstrong (2012:13) menyatakan bahwa Relationship Marketing adalah proses penciptaan, pemeliharaan, dan penguatan hubungan yang kuat dan penuh nilai dengan pelanggan dan pemercaya lain. Pemasaran relasional (relationship marketing) tidak hanya sekedar menciptakan transaksi jangka pendek, pemasar perlu membina hubungan jangka panjang dengan pelanggan, distributor, dan pemasok. Pada dasarnya relationship marketing fokus pada menarik, membangun, dan mempertahankan hubungan jangka panjang dan hubungan kooperatif dengan pelanggan serta dengan para pelanggan potensial.

(Kasmir, 2014:324), mengungkapkan bahwa relationship marketing merupakan sebuah pendekatan untuk menciptakan nilai-nilai ekonomi yang saling menguntungkan antara perusahaan dan pelanggan dengan cara menarik dan menjaga hubungan baik dalam jangka panjang. Hal ini dapat dicapai melalui kerjasama, kolaborasi dan program-program pemasaran yang bertujuan membentuk hubungan yang saling menguntungkan antara perusahaan dengan perantara atau konsumen akhir.

Dalam konsep relationship marketing, menarik pelanggan baru hanyalah salah satu langkah awal dalm proses pemasaran, hal lain yang lebih diperhatikan adalah mempertahankan pelanggan yang sudah ada. Mempertahankan pelanggan yang sudah ada merupakan strategi yang lebih mudah dan murah dari pada mencari pelanggan baru. Pengertian ini memberi implikasi terhadap perubahan dalam cara pandang prusahaan dalam memahami hubungannya dengan pelanggan yang selanjutnya memunculkan suatu prinsip bahwa pengakuan kualitas, customer service, dan aktivitas pemasaran perlu dijalankan bersamaan.

Karakteristik utama relationship marketing menurut Kotler dan Amstrong, (2012:102) adalah sebagai berikut:

a. Memfokuskan diri pada pelanggan dan bukannya pada produk-produk yang dihasilkan perusahaan.

b. Memberikan penekanan terhadap bertahannya dan pertumbuhan pelanggan pada perolehan pelanggan baru.

c. Mengendalikan kerja dari tim-tim yang terdiri dari berbagai fungsi dalam perusahaan daripada kerja yang dilakukan di tingkat departemen.

d. Mengandalkan lebih banyak mendengarkan dibandingkan berbicara. (Syafrudin , 2013:74) ada empat tahapan dalam membangun relationship marketing, yaitu:

a) Melakukan identifikasi dan pencarian konsumen yang paling menguntungkan dengan memperhatikan besarnya kemungkinan atau besarnya laba yang didapat dari penjualan. Perusahaan mungkin dapat melakukan ini dengan cara melakukan segmentasi dan mempelajari riwayat pasar.

b) Memahami profil dari pelanggan, meliputi kebutuhan, gaya hidup, perhatian, pilihan, hasrat dan sikap.

c) Mengembangkan hubungan antara perusahaan dengan pelanggan dengan melakukan kontak, memastikan kontinuitas hubungan, dan hubungan yang berlangsung dalam jangka panjang.

d) Menyesuaikan produk atau jasa yang memperhatikan kebutuhan dari pembeli maupun penjual. 
Menurut Evans dan Laskin dalam (Wibowo, 2010:352), terdapat empat variabel yang dapat digunakan perusahaan dalam mengimplementasikan relationship marketing yaitu:

\section{Memahami Harapan Pelanggan (Understanding Customer Expectation)}

Harapan pelanggan adalah kepercayaan pelanggan sebelum mencoba produk yang diberikan secara standar atau referensi bagaimana produk atau jasa dinilai. Harapan pelanggan pada dasarnya sama dengan layanan seperti apakah yang seharusnya diberikan perusahaan kepada pelanggan. Pelanggan akan menggunakan harapannya sebagai standar atau acuan dalam mengevaluasi layanan yang diberikan oleh perusahaan.

Karena harapan pelanggan berkaitan langsung dengan apa yang telah diraskan oleh pelanggan tentang baik atau buruk suatu produk, kualitas pelayanan yang diberikan, fasilitas yang disediakan dan segala perbaikan dalam sistem manajemen dalam suatu perusahaan yang pengaruhnya berhubungan langsung dengan pelanggan. Umumnya faktor-faktor yang menentukan harapan pelanggan meliputi kebutuhan pribadi, pengalaman masa lampau, rekomendasi dari mulut ke mulut, (word of mouth) dan iklan.

Memahami harapan pelanggan meliputi kemampuan perusahaan untuk mengidentifikasi apa yang pelanggan inginkan dari produk atau jasa telah sesuai atau melebihi apa yang mereka prediksikan sebelumnya (Powers, Evans dan Laskin, dalam (Wibowo, 2010:354). Pada kenyataannya sangat sulit untuk dapat memahami harapan pelanggan dengan baik.

\section{Kerjasama Dengan Pelanggan (Building Service Partnership)}

Kerja sama pada intinya menunjukkan adanya kesepakatan antara dua orang atau lebih yang saling menguntungkan. Moh. Jafar Hafsah menyebut kerja sama dengan istilah "kemitraan", yang artinya adalah suatu strategi bisnis yang dilakukan oleh dua pihak atau lebih dalam jangka waktu tertentu untuk meraih keuntungan bersama dengan prisip saling membutuhkan dan saling membesarkan. Kerjasama dengan pelanggan pada dasarnya menunjukan adanya hubungan saling menguntungkan antara perusahaan dan pelanggan. Menurut Evans dan Laskin dalam (Wibowo, 2010:354) kerjasama dengan pelanggan dipupuk ketika penjualan perusahaan menjadi sering dan berkesinambungan serta semakin dekat dengan pelanggan sehingga menambah keinginan pelanggan untuk mendapatkan produk yang ditawarkan oleh perusahaan. Relationship marketing mendorong lebih banyak kerjasama yang berfokus pada komitmen bersama dan kepercayaan dalam mencapai tujuan yaitu menjalin kerjasama jangka panjang yang erat. Menurut Tulsie (Wibowo, 2010:355) mengatakan bahwa untuk mencapai tujuan ini, perusahaan harus melakukan langkah-langkah sebagai berikut:

1) Membangun hubungan kerjasama dengan pelanggan

2) Menjadi dipercaya oleh pelanggan

3) Menunjukan perhatian kepada pelanggan

4) Mendapatkan kepercayaan dari pelanggan

Ditinjau dari perspektif strategis, hubungan jangka panjang dengan pelanggan memberikan beberapa manfaat bagi perusahaan:

1) Biaya untuk mempertahankan pelanggan lama lebih rendah daripada biaya untuk mendapatkan pelanggan baru.

2) Pelanggan lama yang puas dapat menjadi bagian dari tim penjualan melalui berita baik yang merekasebarkan dari mulut ke mulut (word of mouth).

3) Pelanggan tetap jangka panjang dapat menjadi mitra kerja yang baik bagi perusahaan dalam mengembangkan dan meningkatkan kualitas produk dan jasanya.

4) Perusahaan akan menikmati profitabilitas jangka panjang melalui pembelian dan konsumsi produk atau jasa yang konstan dalam waktu yang lama.

\section{Total Quality Management (TQM)}

Total Quality Management didefinisikan sebagai konsep perbaikan yang dilakukan secara terus menerus, yang melibatkan semua karyawan di setiap level organisasi, untuk mencapai kualitas yang 'exellent' dalam semua aspek organisasi melalui proses manajemen TQM juga didefinisikan sebagai pendekatan manajemen pada suatu organisasi, berfokus pada kualitas dan didasarkan atas partisipasi dari keseluruhan sumber daya manusia dan ditujukan pada kesuksesan jangka panjang melalui loyalitas pelanggan dan memberikan manfaat pada anggota organisasi (sumber daya manusianya) dan 
masyarakat. Menurut Maculay (Wibowo, 2010:355), terdapat empat prinsip yang biasa diterapkan perusahaan yang menjalankan TQM, yaitu:

1) Definisi tuntutan pelangan

Tuntutan pelanggan perlu didefinisikan secara tepat sehingga dengan cepat dan setiap saat dapat dipenuhi menurut harapannya.

2) Pencegahan bukan pembetulan

Lebih baik mengupayakan agar produk dan layanan tidak bertentangan dengan harapan pelanggan daripada memecahkan masalah pada saat sebuah produk akan diselesaikan atau pada saat pemberian layanan.

3) Standar kinerja dan kesalahan nol

Tetapkan standar kinerja yang rinci sehingga produk atau layanan yang sampai ke tangan pelanggan bebas dari kesalahan atau cacat.

4) Pengukuran

Mengukur kerugian yang diambil karena kesalahan atau cacat atas produk maupun layanan dan memeriksa di titik mana yang memerlukan peningkatan. Membandingkan kinerja yang ditargetkan dengan yang terjadi sebenarnya.

\section{Pemberdayaan Karyawan (Empowering Employees)}

Pemberdayaan berarti memampukan (to enable), memberi kesempatan (to allow), atau mengizinkan (to permit), yang dapat diartikan baik melalui inisiatif sendiri atau dipacu oleh orang lain. pemberdayaan adalah merupakan pemberian tanggung jawab dan wewenang terhadap pekerjaan untuk mengambil keputusan menyangkut semua pengembangan produk dan pengambilan keputusan.

Pemberdayaan karyawan secara umum berarti menempatkan karyawan di barisan terdepan dalam menyelesaikan masalah yang dihadapi oleh pelanggan Evans dan Laskin, (Wibowo, 2010:3357). Karyawan menjadi semakin dekat dengan pelanggan dan menjadi yang pertama tahu tentang masalah yang dihadapi pelanggan sehingga karyawan akan mengetahui apa yang dibutuhkan untuk memuaskan pelanggan. Definisi lain dari pemberdayaan karyawan adalah memampukan dan memberi kesempatan kepada karyawan untuk merencanakan, mengimplementasikan rencana, dan mengendalikan imlementasi rencana pekerjaan yang menjadi tanggung jawabnya. Tujuan dari pemberdayaan karyawan yaitu untuk memunculkan potensi dan modalitas yang ada dalam diri karyawan dan memaksimalkannya sehingga karyawan menjadi mandiri dan meningkat kinerjanya, yang pada akhirnya memberikan nilai manfaat bagi karyawan dan organisasi.

Menurut Evans dan Laskin dalam, (Wibowo, 2010:359) untuk pemberdayaan karyawan terdapat empat kondisi yang harus dipenuhi yaitu:

1) Kegiatannya harus berhubungan dengan misi perusahaan.

2) Karyawan harus mempunyai kemampuan menyelesaikan masalah dan membuat keputusan.

3) Karyawan harus mempunyai tanggung jawab dan wewenang untuk membuat keputusan yang memberi pelayanan terbaik bagi konsumen.

4) Perusahaan harus menaruh dan memelihara semangat bahwa pekerjaan itu tidak berisiko jika diambil pemberdayaan oleh karyawan itu sendiri.

\section{Loyalitas}

Loyalitas didefinisikan sebagai suatu sikap yang ditujukan oleh konsumen terhadap penyediaan produk atau jasa. Seorang konsumen akan menunjukan sikap loyalnya jika suatu perusahaan mampu memberikan kepuasan kepada konsumennya. Konsumen yang loyal adalah seorang konsumen yang selalu membeli kembali dari provider atau penyedia jasa yang sama dan memilihara suatu sikap positif terhadap penyedia jasa itu dimasa yang akan datang (Griffin, 2015;4).

Definisi diatas menyatakan bahwa loyalitas pelanggan merupakan sebuah komitmen yang kuat untuk membeli ulang terhadap suatu produk atau jasa secara konsisten di waktu yang akan datang, dengan demikian menyebabkan perulangan pada merek yang sama atau membeli merek yang sama, walaupun kondisi situasional dan usaha-usaha pemasaran mempunyai pengaruh yang potensial dalam perilaku perpindahan merek.

Seorang pelanggan loyal adalah seorang pelanggan yang sering mengulangi pembelian, membeli lini produk atau jasa serta mempunyai tingkat kekebalan terhadap perusahaan pesaing (Hasibuan, 2012:55). Menurut Evans dan Laskin dalam (Wibowo,2010:362) pelanggan yang loyal adalah pelanggan yang akan melakukan pembelian ulang dari penyedia jasa yang sama, yang mungkin atau mungkin tidak untuk jenis produk atau jasa yang sama, menyebarkan berita dari mulut ke mulut (word of mouth) yang 
positif dan kebal terhadap bujukan pesaing. Kotler, Hayes dan Bloom dalam (Griffin, 2015:12) menyebutkan ada enam alasan mengapa suatu institusi atau perusahaan perlu mendapatkan loyalitas pelanggannya, yaitu:

a. Pelangan loyal yang ada lebih prospektif, artinya pelanggan loyal akan memberi keuntungan besar kepada institusi.

b. Biaya mendapatkan pelanggan baru jauh lebih besar dibandingkan dengan menjaga dan mempertahankan pelanggan yang sudah ada.

c. Pelanggan yang sudah percaya pada institusi dalam suatu urusan akan percaya juga dalam urusan lainnya.

d. Biaya operasi institusi akan menjadi lebih efisien jika memiliki banyak pelanggan yang loyal.

e. Institusi dapat mengurangkan biaya psikologis dan sosial, hal ini dikarenakan pelanggan yang loyal telah mempunyai banyak pengalaman positif dengan institusi.

f. Pelanggan yang loyal akan selalu membela institusi bahkan berusaha pula untuk menarik dan memberi saran kepada orang lain untuk menjadi pelanggan yang loyal.

Indikator dari loyalitas pelanggan menurut Kotler dan Keller (2012:57) adalah sebagai berikut:

A. Kepercayaan Nasabah Pada Perusahaan Merupakan sikap positif atas kepercayaan nasabah akan keamanan dan perlindungan atas produk dan jasa yang ditawarkan oleh perusahaan kepada pelanggan.

B. Membeli Ulang Produk

Seorang pelanggan yang melakukan pembelian yang berulang-ulang (kesetiaan terhadap pembelian produk). Konsumen yang loyal adalah mereka yang berkomitmen tinggi untuk membeli kembali dan berlangganan suatu produk atau jasa secara konsisten dimasa yang akan datang, sehingga dapat menyebabkan pengulangan pembelian merek yang sama.

C. Nasabah Tidak Menggunakan Jasa Bank Lain

Seorang pelanggan yang menunjukkan ketahanan dari daya tarik pesaing (tidak tertarik dengan produk yang sama dari perusahaan lain). Pelanggan yang loyal akan melakukan pembelian produk perusahaan secara berulang dan tidak tertarik dengan produk perusahaan pesaing yang sejenis.

D. Merekomendasikan Pada Orang Lain

Pelanggan dengan loyalitas yang tinggi, selain akan membawa keuntungan dalam hal ini pendapatan jangka panjang, mereka juga berfungsi sebagai penasehat bagi orang lain untuk turut menjadi pelanggan.

\section{Kerangka Analisis}

\begin{tabular}{|c|c|}
\hline $\begin{array}{c}\text { Relationship Marketing } \\
\text { (X) }\end{array}$ & $\begin{array}{c}\text { Loyalitas Nasabah } \\
\text { (Y) }\end{array}$ \\
\hline $\begin{array}{l}\text { Memahami Harapan } \\
\text { Pelanggan (X1) }\end{array}$ & $\begin{array}{l}\text { Kepercayaan Nasabah } \\
\text { Pada Perusahaan (Y1) }\end{array}$ \\
\hline $\begin{array}{l}\text { Kerjasama Dengan } \\
\text { Pelanggan (X2) }\end{array}$ & $\begin{array}{l}\text { Membeli Ulang Produk } \\
\text { (Y2) }\end{array}$ \\
\hline $\begin{array}{l}\text { Total Quality Managenent } \\
(X 3)\end{array}$ & $\begin{array}{l}\text { Nasabah Tidak } \\
\text { Menggunakan Jasa Bank } \\
\text { Lain (Y3) }\end{array}$ \\
\hline $\begin{array}{l}\text { Pemberdayaan Karyawan } \\
\text { (X4) }\end{array}$ & $\begin{array}{l}\text { Merekomendasikan Pada } \\
\text { Orang Lain (Y4) }\end{array}$ \\
\hline
\end{tabular}

Gambar 1. Kerangka Analisis 


\section{Metode Penelitian}

Jenis penelitian yang dilakukan adalah deskriptif analisis, menurut sugiyono, (2013:78) penelitian deskriptif merupakan metode penelitian yang berusaha menggambarkan dan menginterprestasi objek sesuai dengan apa adanya. Penelitian ini juga sering disebut non eksperimen, karena pada penelitian ini tidak melakukan kontrol dan manipulasi variabel penelitian. Dengan metode deskriptif analisis penelitian memungkinkan untuk melakukan hubugan antar variabel, menguji hipotesis, mengembangkan generalisasi, dan mengembangkan teori yang memiliki validitas iniversal.

Untuk mengetahui antara variabel (X) relationship marketing dan variabel (Y) loyalitas Nasabah digunakan korelasi Rank Spearman (Sugiyono, 2013) dengan rumus sebagai berikut :

$$
\begin{aligned}
& \rho--\frac{6 \sum_{b i} 2}{n\left(n^{2}-1\right)} \\
& \text { Dimana : } \\
& \rho \quad \text { : koefisien korelasi rank spearman } \\
& n \quad \text { : jumlah kasus atau sampel } \\
& \sum \text { bi2: jumlah kuadrat darai selisih rank variabel } \mathrm{x} \text { dan } \mathrm{y}
\end{aligned}
$$

Untuk mengetahui apakah terdapat hubungan yang berarti (signifikan) atau tidak berarti antara kedua variabel tersebut, maka digunakan Unji “t” dengan menggunakan rumus (Sugiyono, 2013 :246) :

$$
\begin{aligned}
& t=r \frac{\sqrt{n-2}}{\sqrt{\left(1-r^{2}\right)}} \\
& \text { Keterangan : } \\
& \text { T : t-hitung } \\
& \mathrm{N} \quad \text { : jumlah sampel } \\
& \text { R : koefisien korelasi } \\
& \mathrm{r}^{2} \quad \text { : koefisien korelasi yang diterima }
\end{aligned}
$$

\section{Hasil Penelitian Dan Pembahasan Analisis Korelasi Spearman Rank}

Dari persepsi responden terhadap indikator penelitian baik indikator variabel relationship marketing maupun indikator loyalitas nasabah, menunjukan bahwa semakin baik implementasi relationship marketing kepada nasabah, maka semakin tinggi loyalitas nasabah yang menggunakan produk atau jasa PT. Bank BRI Syariah Kantor Cabang Bengkulu. Untuk mengetahui hubungan antara implementasi relationship marketing (X) dengan loyalitas nasabah (Y) di PT. Bank BRI Syariah Kantor Cabang Bengkulu, akan digunakan analisa deskriptif dan kuantitatif dengan pendekatan statistik (descriptive statistic) menggunakan rumus spearman rank.

Dari tabel penolong untuk menghitung koefisien korelasi spearman rank pada lampiran 4 diketahui nilai-nilai sebagai berikut :

$$
\begin{array}{ll}
\Sigma_{b i} 2 & =13.430 \\
n & =70
\end{array}
$$

Selanjutnya nilai-nilai tersebut dianalisi untuk mengetahui hubungan iplementasi relatioship marketing dengan loyalitas nasabah di PT. Bank BRI Syariah Kantor Cabang Bengkulu, sebagai berikut:

$$
\begin{aligned}
& \rho=1-\frac{6 \sum b i^{2}}{n\left(n^{2}-1\right)} \\
& \rho=1-\frac{6 \times 13.430}{70\left(70^{2}-1\right)} \\
& \rho=1-\frac{80.580}{70(4899)} \\
& \rho=1-\frac{80.580}{342.930}
\end{aligned}
$$




$$
\begin{aligned}
& \rho=1-0.235 \\
& \rho=0.765
\end{aligned}
$$

sebagai berikut :

Menurut Sugiono, (2010:113) pedoman untuk memberi interpretasi koefisien korelasi

$0,00-0,199=$ Sangat Rendah

$0,20-0,399=$ Rendah

$0,40-0,599=$ Sedang

$0,60-0,799=$ Kuat

$0,80-1,000=$ Sangat Kuat

Dari hasil perhitungan diatas diperoleh nilai koefisien korelasi spearman rank atau rho hitung $(\rho)$ sebesar 0,765 berada pada interval korelasi 0,60 - 0,799 dengan kriteria kuat , artinya implementai relationship marketing mempunyai hubungan yang kuat dengan loyalitas nasabah di PT. Bank BRI Syariah Kantor Cabang Bengkulu.

\section{Uji Hipotesis}

Hasil perhitungan analisis korelasi spearman rank di atas diperoleh nilai $(\rho)=0,765$ dengan $n=$ 70. Dari hasil ini akan dilakukan uji hipotesis untuk menguji kuatnya hubungan implementasi relationship marketing dengan loyalitas nasabah pada PT. Bank BRI Syariah Kantor Cabang Bengkulu dengan menggunakan uji t, sebagai berikut :

$$
\begin{aligned}
t_{\text {hitung }} & =\rho \frac{\sqrt{n-2}}{1-\rho^{2}} \\
t_{\text {hiowng }} & =0,765 \frac{\sqrt{68}}{\sqrt{1-0,585}} \\
t_{\text {hitung }} & -0,765 \frac{\sqrt{68}}{\sqrt{0,415}} \\
t_{\text {hitung }} & =0,765 \sqrt{163.855} \\
t_{\text {hitung }} & =0,765(12.800) \\
t_{\text {hitung }} & =9.792
\end{aligned}
$$

Dari hasil uji hipotesis diperoleh nilai $t_{\text {hitung }}$ 9.792, kemudian nilai tersebut dibandingakan dengan nilai $t_{\text {tabel }}$ dengan taraf signifikan atau tingkat kepercayaan 95\% diperoleh nilai 1,66757 dan $\mathrm{dk}$ $=\mathrm{n}-2=68$, dengan kriteria :

a. jika $t_{\text {hitung }} \leq t_{\text {tabel }}$, maka Ha diterima atau korelasinya tidak signifikan (tidak ada hubungan)

b. jika $t_{\text {hitung }} \geq t_{\text {tabel }}$, maka Ho ditolak atau korelasinya signifikan (terdapat hubungan signifikan) hasil uji hipotesis diketahui bahwa $t_{\text {hitung lebih besar dari }}$ $t_{\text {tabel }}\left(t_{\text {hitung }} \geq t_{\text {hitung }}=9,792 \geq 1,66757\right)$ dengan demikian hasil hipotesis adalah Ho ditolak dan Ha diterima, artinya implementasi relationship marketing (X) mempunyai hubungan yang signifikan dengan loyalitas nasabah (Y) pada PT. Bank BRI Syariah Kantor Cabang Bengkulu.

\section{Pembahasan}

Berdasarkan hasil penelitian menunjukan bahwa implementasi relationship markering pada PT. Bank BRI Syariah Kantor Cabang Bengkulu sangat baik yang ditunjukan dengan persepsi nasabah pengguna produk atau jasa dengan nilai 4.40 berada pada interval $4.20-5.00$ dengan kriteria sangat baik. Begitu juga dengan loyalitas nasabah, bahwa persepsi terhadap loyalitas nasabah diperoleh nilai rata-rata 4.49 yang berada pada interval 4.20 - 5.00 dengan kriteria sangat baik, hasil positif juga didapat dari ratarata tertinggi variabel Relationship Marketing pada dimensi Kerjasama Dengan Pelanggan dengan nilai sebesar 4.47 dan variabel Loyalitas Nasabah pada dimensi Membeli Ulang Produk sebesar 4.57. artinya rata-rata nasabah nasabah yang menggunakan produk atau jasa PT. Bank BRI Syariah Kantor Cabang Bengkulu sangat puas dengan produk dan jasa yang diberikan. 
Menurut sugiono, (2010: 113) ada hubungan yang positif yang signifikan antara variabel (X) dengan $(\mathrm{Y})$ berarti hubungan antara dua variabel semakin kuat. Hasil yang diperoleh nilai koefisien korelasi spearman rank atau rho hitung $(p)$ sebesar 0,765 berada pada interval korelasi 0,60 - 0,799 dengan kriteria kuat, artinya implementasi relationship marketing mempunyai hubungan yang kuat dengan loyalitas nasabah PT. Bank BRI Syariah Kantor Cabang Bengkulu. Berdasarkan hasil uji hipotesis terhadap koefisien korelasi rank spearman diperoleh $\mathrm{t}$ hitung 9.792 selanjutnya nilai $t_{\text {hitung }}$ tersebut dibandingkan dengan nilai $t_{\text {tabel }}$ pada tingkat keyakinan $95 \%$ atau tingkat kesalahan $5 \%$ diketahui nilai $\mathrm{t}$ table adalah 1,66757, artinya bahwa nilai t hitung lebih besar dari nilai t tabel $(9.792>1.66757)$ maka hipotesis yang diajukan dalam penelitian ini dapat diterima artinya ada hubungan positif yang signifikan antara variabel relationship marketing (X) dengan loyalitas nasabah (Y) pada PT. Bank BRI Syariah Kantor Cabang Bengkulu.

\section{KESIMPULAN}

1. Persepsi responden terhadap variabel relationship marketing sangat baik yang ditunjukan dengan persepsi nasabah pengguna produk atau jasa dengan nilai 4.40 berada pada interval $4.20-5.00$ dengan kriteria sangat baik. Begitu juga dengan loyalitas nasabah, bahwa persepsi terhadap loyalitas nasabah diperoleh nilai rata-rata 4.49 yang berada pada interval $4.20-5.00$ dengan kriteria sangat baik, artinya rata-rata nasabah nasabah yang menggunakan produk atau jasa PT. Bank BRI Syariah Kantor Cabang Bengkulu sangat puas dengan produk dan jasa yang diberikan.

2. Hasil uji koefisien korelasi sprearman rank diperoleh rho hitung $(\rho)$ sebesar 0,765. Berada pada interval korelasi 0,60 - 0,799 dengan kriteria kuat, artinya implementasi relationship marketing mempunyai hubungan yang kuat dengan loyalitas nasabah PT. Bank BRI Syariah Kantor Cabang Bengkulu.

3. Hasil uji hipotesis dengan t-tes diketahui implementasi relationship marketing berpengaruh signifikan dengan loyalitas nasabah PT. Bank BRI Syariah Kantor Cabang Bengkulu dengan hasil thitung $\geq$ tabel $(9,792 \geq 1,66757)$.

\section{SARAN}

1. Disarankan kepada perusahaan agar selalu konsisten dan meningkatkan produk dan layanan secara terus menerus dan menjadikan nasabah sebagai prioritas.

2. Disarankan kepada Perusahaan untuk terus meningkatkan keamanan setiap produk atau jasa yang ditawarkan mengingat keamanan dan kenyamanan nasabah menjadi salah satu penentu dalam menciptakan loyalitas nasabah.

\section{DAFTAR PUSTAKA}

Chan, Syafruddin. 2010. Relationship Marketing : Inovasi Pemasaran yang Membuat Pelanggan Bertekuk Lutut. Jakarta: PT. Gramedia Pustaka Utama.

Daniel, Moehar. 2012. Pengantar Ekonomi. Jakarta: PT. Buni Aksara

Fandy, tjiptono. 2012. strategi pemasaran. edisi kedua. yogyakarta: Penerbit Andi.

Griffin, Jill. 2013. Customer Loyalty, Menumbuhkan dan Mempertahankan Kesetiaan Pelanggan.Jakarta: Erlangga.

Hasan, Ali. 2013. Marketing dan Kasus - kasus Pilihan. Yogyakarta: CAPS (Center for Academic Publishing Service).

Hasibuan. 2012. Manajemen Sumber Daya Manusia. Cetakan ke-11. Jakarta: PT.Bumi Aksara

Kasmir. 2014. Pemasaran bank, Jakarta: PT. Gafindo Persada

Kotler, Philip dan Kevin, Keller. 2013. Manajemen Pemasaran, Edisi 12 Jilid 1. Jakarta: PT. Indeks.

Prasasti. 2013. Manajemen Strategik. Yogyakarta: Ekonesia.

Rambat, Lupiyoadi, Dan A. Hamdani. 2011. Manajemen Pemasaran Jasa. Edisi Kedua. Jakarta: Salemba Empat.

Rivai dan Basri. 2014. Mnanjemen Perbankan, Teori Dan Aplikasi, edisi 12 Jilid II. Jakarta: PT. INDEKS.

Sugiyono. 2013. Metode Penelitian Bisnis, Cetakan Ketujuh. Bandung: Penerbit CV. Alfabeta.

Tjiptono, Fandy. 2012. Pemasaran Jasa, Edisi Kedua. Jakarta: PT.Prenhalindo. 
Hubungan Iklan Dan Citra Merek Dengan Keputusan Pembelian Shampo Clear

Pada Swalayan Fadillah Kota Bengkulu

Tandjung, J. Widodo. 2010. Marketing Management Pendekatan Pada Nilai-Nilai Pelanggan.. Malang: Bayumedia Publishing

Nurdin dan Usman. 2012. Guru Profesional dan Implementasi Kurikulum. Jakarta: Ciputat Press.

Wibowo. 2010. Implementasi Relationship Marketing pada Industri Hospitality, Jakarta: Utilitas. 